\title{
Landslide vulnerability assessment in Gangotri valley glacier Himalaya through GIS and remote sensing techniques
}

\author{
Naval Kishore Tewari ${ }^{1} \cdot$ Anil Kumar Misra $^{2}$
}

Received: 26 August 2018 / Accepted: 16 May 2019 / Published online: 25 May 2019

(c) The Author(s) 2019

\begin{abstract}
Almost every year, landslide damages several villages, road connectivity and important infrastructure set-ups along with many casualties and injuries to the people living in the Gangotri valley glacier area. This glacier valley is surrounded by high peaks, and it represents one of the largest glaciers in the western Himalaya. The fluctuations in climatic conditions and prevailing glacial, fluvio-glacial and fluvial processes resulted in the diversified landforms throughout the region. In the present study, remote sensing and GIS techniques have been used to generate various models like digital elevation model, digital terrain model and maps like aspect map, slope map and altitudinal zones map of Gangotri valley glacier area. Using these models and maps, landslide vulnerability assessment was carried out which is essential for making the disaster risk management strategy for the study area. The digital elevation model shows a gradual escalation in elevation towards SW direction. Digital terrain model indicates that the number of tributary glaciers and associated landforms on either side of the valley was more in number in the past. Data of aspect map show that NE part is most sensitive for avalanche and the slope map indicates the important sites for choking of the Bhagirathi River due to debris and mass flow. The outcome of this study will be helpful in landslide vulnerability assessment along the formation of Bhagirathi River disaster risk reduction plan.
\end{abstract}

Keywords Landslide assessment · Gangotri glacier · Bhagirathi River · Garhwal Himalaya · GIS · Digital terrain model

\section{Introduction}

Himalayan geology attracted geoscientists from different parts of world following classical synthesis of various geomorphic features (Gansser 1964). Among other aspects, a great deal of attention is paid to study the fascinating Himalayan glaciers, particularly the largest Gangotri valley glacier of Garhwal (Valdiya 2010; Mathew et al. 2007; Nainwal and Prased 2002; Philip and Ravindran 1998; Puri and Shukla 1996; Sangewar 1998; Singh and Yadav 2000; Tangri 2002; Tewari and Sharma 2015; Valdiya 1993; Yadav et al. 1997, 1999; Yadav and Park 2000; Yadav and Singh 2002). The

Anil Kumar Misra

anilgeology@gmail.com; akmisra@cus.ac.in

Naval Kishore Tewari

navalkt@yahoo.com

1 Department of Geology, Sri JNPG College, Lucknow 226001, India

2 Department of Geology, School of Physical Sciences, Sikkim University (A Central University), Tadong, Gangtok, Sikkim 737102, India early landform mapping and determination of snout position of Gangotri glacier by Auden (1937) were subsequently followed by several workers (Valdiya 2010). Attempts have been made to analyse and interpret the climate variation and retreat of Gangotri glacier on the basis of landforms and other morphometric parameters (Naithani et al. 2001; Bali et al. 2003, 2004). However, little attention is focussed to analyse and interpret Gangotri glacier valley using more reliable and precise remote sensing and GIS methods with the help of IRS-PAN satellite data.

The remote sensing and GIS techniques are one of the most efficient tools for terrain evaluation and interpretation especially in remote regions. The synoptic coverage and high precision of remotely sensed data are an extremely effective tool in all geomorphological data analysis and interpretation. The data derived from different sources such as satellite data, ground surveys and collateral data provide an integrated account for generating map information. Such studies are quite useful in town planning and in demarcating areas prone to landslides especially in mountain regions. Till date, detailed GIS studies of Gangotri valley glacier have not been 
carried out except the preliminary work by Singh and Mishra (2000).

The aim of the present study is to generate various models and maps (DTM, DEM, aspect map, slope map, etc.) by analysing IRS-PAN satellite data for landslide vulnerability assessment. The integrated results together will help in preparing a disaster risk reduction plan in landslide-prone areas of Gangotri valley glacier.

\section{Gangotri glacier and Bhagirathi valley}

The Gangotri glacier of Garhwal is characterized by varied landforms and represents one of the largest glaciers in the western Himalayan region. It originates from Chaukhamba group of peaks at an altitude of about $7100 \mathrm{msl}$; the snout is at more than $4000 \mathrm{msl}$ and extends for about $30 \mathrm{~km}$ in length covering an area of about $75 \mathrm{sq} . \mathrm{km}$. The Gangotri glacier lies between latitudes $30^{\circ} 44^{\prime} \mathrm{N}$ to $30^{\circ} 56^{\prime} \mathrm{N}$ and longitudes $79^{\circ} 04^{\prime} \mathrm{E}$ to $79^{\circ} 15^{\prime} \mathrm{E}$ (Survey of India, 2000). The entire Gangotri glacier is situated in a highly seismic zone (zone IV) and shows intense neo-tectonic activities. The area situated in north of the Main Central Thrust (passing south of Bhatwari) comprises migmatites, banded augen gneisses, garnet-mica schists, kyanite schists, biotite quartz schists and Gangotri granite. The analysis of IRS-PAN satellite data, Survey of India toposheet and field study identifies several diverse geomorphological features throughout Gangotri glacier and Bhagirathi valley of Garhwal Himalaya. These include moraines, supra-glacial lakes, river terraces, kame terraces, fluvio-glacial fans, till deposits, etc. The snout of the Gangotri glacier is at Gaumukh, a distance of about $19 \mathrm{~km}$ from the Gangotri town. The top surface of the glacier is full of crevasses, 5-10 $\mathrm{m}$ in length and 1-3 m in width. The glacier surfaces as well as the crevasses are often overlain by supra-glacial moraines debris. Along the margins of the ice cave and the top surface of the glacier, a number of longitudinal as well as transverse crevasses are observed. The transverse crevasses are mostly in the E-W direction and dipping nearly vertical or at high angles. Such features are typically associated with the Meru Bamak, Bhrigupanth Bamak and Manda Bamak along the left bank and Raktavarna Bamak and Matri Bamak on the right bank of the Bhagirathi River. Most of the recessional moraines are composed of material ranging from silt/sand size particles to huge boulders. Very often, the recessional moraines are modified or obliterated by later fluvial activities. The oldest terminal moraine of the Gangotri glacier is reported to be present at Sukhi top, near Jhala, which probably represents the snout during the Pleistocene glaciation (Sharma and Owen 1996; Owen 1989; Owen et al. 1995; Owen and Sharma 1998).
The river Bhagirathi, originating from the Gangotri glacier at Gaumukh, follows north-westerly slopping valley up to Gangotri township and flows in a westerly direction up to Harsil and then southwards further downstream (Fig. 1). A little upstream of Bhojbas, the river, has incised through the recent fan deposits, thus exposing the vertical face of the terrace/fan, standing at about $2 \mathrm{~m}$ above the valley floor. The formation of terraces and vertical faces is manifestation of neo-tectonic activities in the area (Bali et al. 2003). The area between the right valley wall and the right lateral moraine is marked by the presence of kame terrace deposits forming nearly flat ground at an elevation of about $300 \mathrm{~m}$ above the present valley floor. The valley, apart from being very wide between the snout and Chirbas, is also marked by the presence of a number of symmetrical and asymmetrical fluvioglacial fans. Narrow pyramidal till deposits are prominently seen about $2.5 \mathrm{~km}$ downstream of Bhujbas on the right bank,

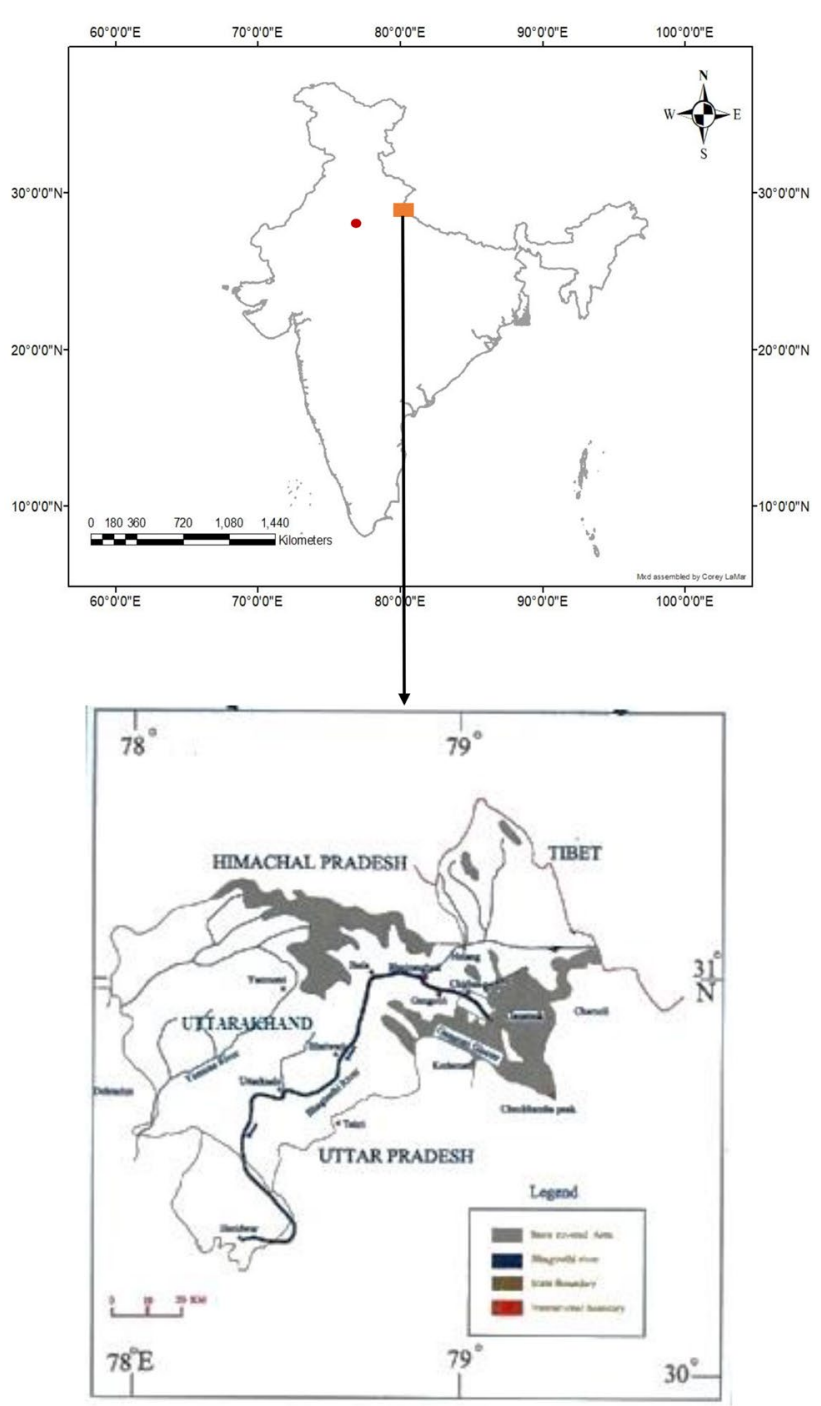

Fig. 1 Location map of the Gangotri glacier, Garhwal Himalaya 
capped by large boulders, which protect them from denudation. These deposits occur in a linear fashion and are oriented transverse to the valley. The glacially eroded terraces seem to have formed as a result of glacial erosion and are typically marked by abrupt break in slopes of the general U-shaped profile of the valley. The four prominent levels of terraces indicate the altitude, at which the trunk glacier had stabilized for some time during its recession. In general, unpaired terraces are present, however, at places; the paired terraces are also observed (Bali et al, 2003). The broader segments have very low gradient and extensive deposits of glacial out wash, as a result of which the channel shows a braided pattern. The region to the south of snout up to Chirbas is traversed by NW-SE-trending Gaumukh fault (Bali et al. 2003). A number of terraces mark the entrenchment of Bhagirathi River in this part. The contrasting drainage morphometric parameters of two sides of the valley and asymmetrical recessional patterns of the tributary glaciers are further evidences of movement along the fault. The neotectonic activity that followed deglaciation controls distribution and orientation of debris fans and has brought the glacially carved wide U-shaped valley in contact with the present fluvial incised, narrow and relatively deep valley.

\section{Methodology}

In the present study, IRS-ID LISS-III satellite data (Path/ Row 097/049) were used for mapping the land forms of the area (Fig. 2). Pre-processing of the data was carried out by Erdas Imagin 8.5 software and visual interpretation using Arc view 8.3 software. The data collection for this study involves collection of toposheet and satellite data. The Survey of India toposheet of 1:50,000 was used in the present study.

The boundaries of the geological units were checked and modified on the basis of image characteristics as well as field observations. The slope map of the area was generated with the help of digital elevation model (DEM). Visual interpretation techniques were used in delineation of geomorphic units based on the tone, texture, shape, drainage pattern, colour and differential erosion characteristics of the satellite images in conjunction with collateral information. The boundary delineation of geomorphic units was carried out on the basis of changes in topographic slope, relief pattern, drainage pattern and image characteristics of the area. The drainage parameters were analysed to assess their influence on genesis of geomorphic units, characteristics and their processes. Accuracy assessment is based on estimating commission and omission errors. Detailed field checks are conducted on selected sites to verify the boundaries and properties of delineated geomorphic units before finalizing the geomorphological map of the area.

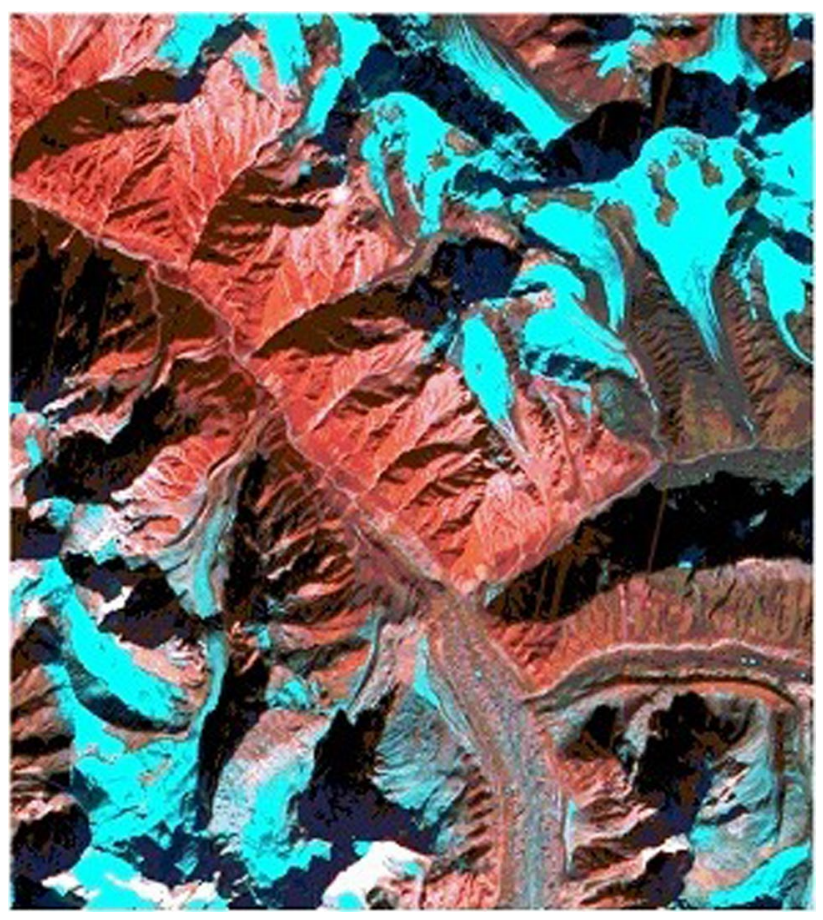

Fig. 2 LISS-III satellite data of the Gangotri glacier, Garhwal Himalaya

The following maps/models were prepared.

(1) DEM (digital elevation model)

(2) DTM (digital terrain model)

(3) Aspect map (slope directional map)

(4) Slope shape

(5) Relief map

(6) Slope aspect

\section{Results and discussion}

\section{DEM (digital elevation model)}

Using contour and spot height as input data from the Survey of India toposheet, a three-dimensional model of the study area was prepared. Digital elevation model signifies the virtual three-dimensional framework of the specified area, which is a close approximation to that of the actual. The input required to obtain a DEM is the elevation information about the area in the form of contours, spot height, benchmark, altimeter reading, etc. These sets of information (height information) along with the spatial location $(x, y)$ are entered into required GIS processing software Arc view-8.3 to obtain interpolated apparent height for each point with in the area.

The accuracy of the model depends upon the:

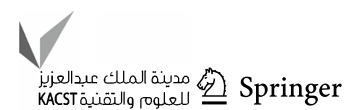


(1) Distance between two consecutive points, lines, etc.

(2) Accuracy of $(x, y)$ position for a specific height point or line.

(3) Accuracy of elevation information of the input data.

The digital elevation model covers the area between Gaumukh and Chirbas. The elevation of Bhagirathi River is $4000 \mathrm{~m}$ at Gaumukh (snout) and $3560 \mathrm{~m}$ at Chirbas. The maximum elevation is recorded at accumulation zone of the Gangotri glacier which is approximately $6426 \mathrm{~m}$ at $30^{\circ} 43^{\prime} 22^{\prime \prime}-30^{\circ} 55^{\prime} 49^{\prime \prime}$ (latitude) and 79 $4^{\prime} 41^{\prime \prime}-79^{\circ} 16^{\prime \prime} 34^{\prime \prime}$ (longitude). There is an increase in elevation towards the southeast direction of the Gaumukh, while a decrease in elevation is seen towards the northwest. The model shows minimum elevation near Chirbas and its downstream. The DEM shows that the elevation at Gaumukh and its surroundings varies between 4000 and $4200 \mathrm{~m}$. The altitude recorded at different locations of Bhojbas, Bhujgari and Chirbas is $3843 \mathrm{~m}, 3730 \mathrm{~m}$ and $3560 \mathrm{~m}$, respectively. It implies a gradual increase in elevations towards SW in comparison with NE (Fig. 3). About 0.12 sq. km. of area shows minimum altitude varying between 2200 and $2529 \mathrm{~m}$. Approximately 31.30 sq. $\mathrm{km}$ area of the study region shows the maximum heights between 4477 and $5127 \mathrm{~m}$. Likewise, about 29.14 sq. $\mathrm{km}$ of area shows the altitude range of 3828-4477 $\mathrm{m}$. Area ratio between the maximum and minimum elevation range is about 1:270.

DEMs in vector format are often in the form of triangulated irregular networks (TIN) and seen as a series of polygons in the form of triangle in between three points. Each triangle has a uniform slope with respect to steepness and slope direction. When the terrain is more complex, the number of triangles desired to represent the terrain increases. The TIN of the study area gives a clear picture about the elevation and it variation with $(x, y)$ space. The elevation of the area varies from 2600 to $6400 \mathrm{~m}$. The DEM represents the slope gradient area, and therefore, it is very useful in estimating the direction of sediment transport and so as the provenance (Fig. 4).

\section{DTM (digital terrain model)}

Digital terrain model is digital representation of the altitude of the terrain surface such as land use, soil type, rock type and hydrological condition (Fig. 5). It is developed using GIS software Arc view 8.3. There are evidences that the Gangotri glacier was several kilometres downstream from its present position (Sharma and Owen 1996). Presuming the snow line to be $300 \mathrm{~m}$ lower in elevation than the present snow line, all the troughs of digital terrain model should be covered by ice. It is indicated in several earlier studies that when the snout was up to Gangotri town, the snow line was at $3000 \mathrm{~m}$ elevation (Sharma and Owen 1996) so the valley demarcated in the digital terrain model towards the SE and NW direction should have been fully covered by ice. It implies that the number of tributary glaciers and the associated landforms on either sides of the valley was more in the past. The main valley vacated by the Gangotri glacier is transformed gradually from a U-shaped characteristics glacial valley to a $\mathrm{V}$-shaped valley by the paraglacial processes.
Fig. 3 Digital elevation model of the Gangotri glacier area

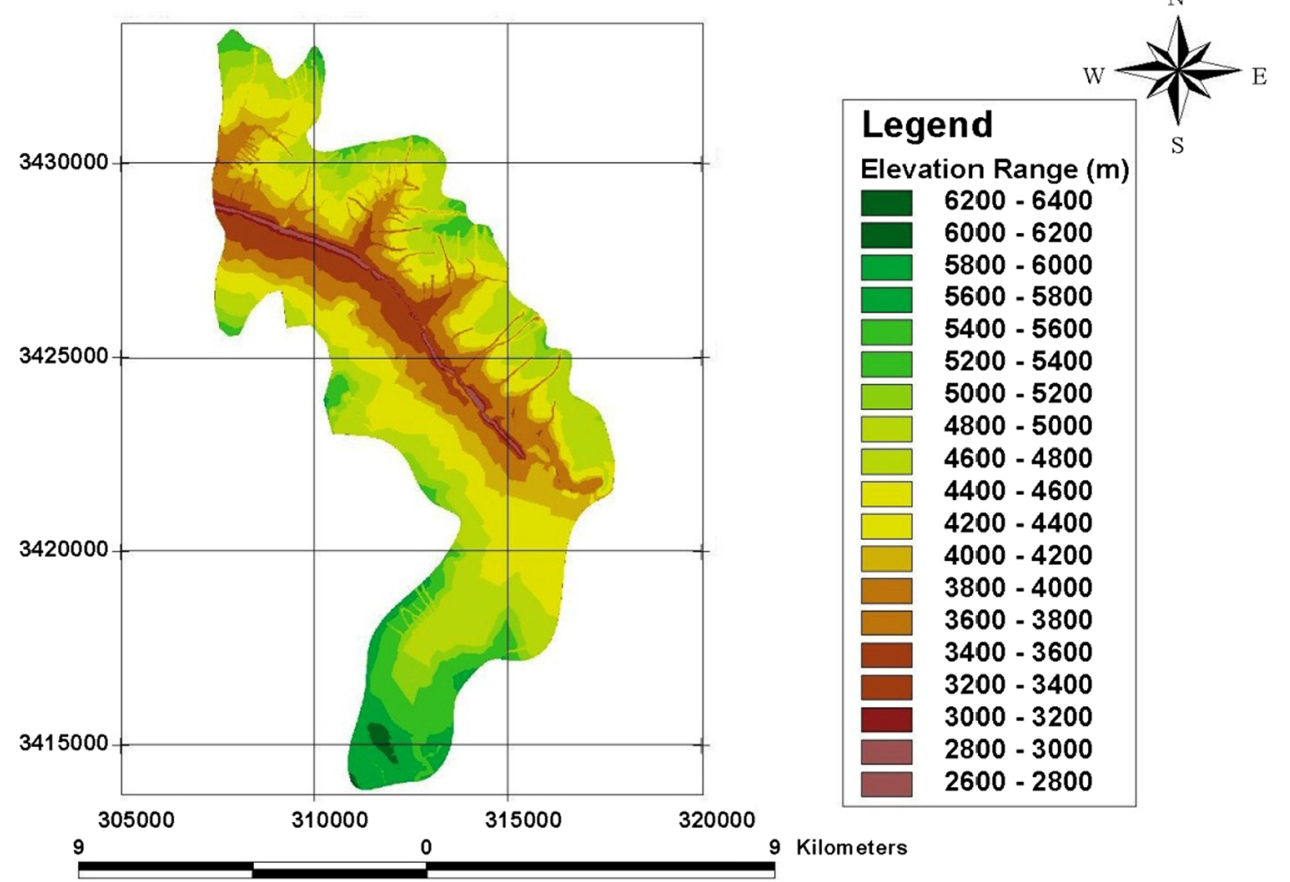


Fig. 4 Triangulated irregular networks (TIN) model of the Gangotri glacier area

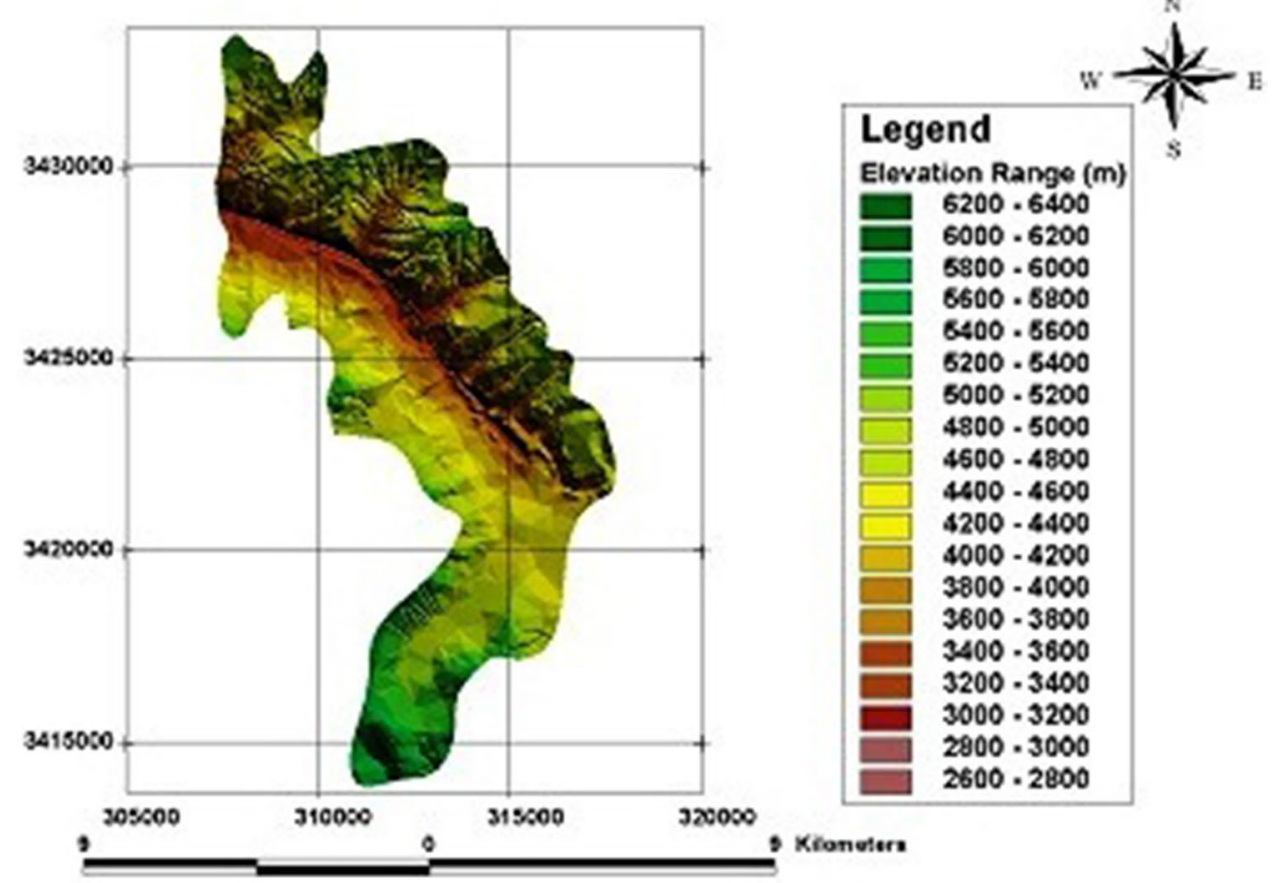

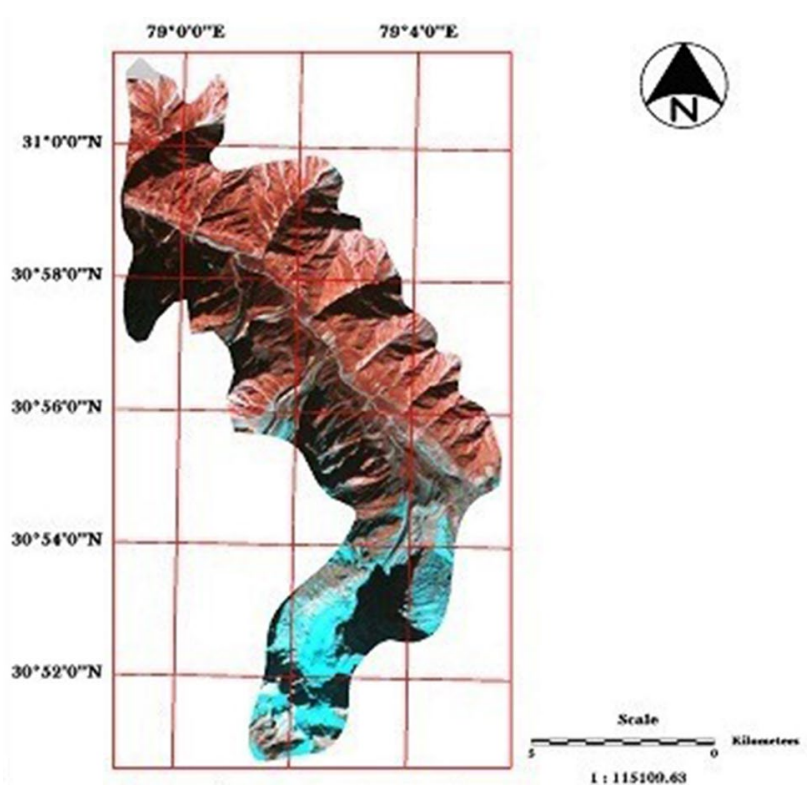

Fig. 5 Digital terrain model (DTM) of the Gangotri glacier area

At Bhojbas, the valley is V-shaped, and near Gaumukh, it is U-shaped suggesting that the paraglacial processes are presently dominating in the valley. The Bhagirathi River from Gaumukh to Chirbas shows the meandering, braided and straight nature at different locations. Due to extremely heterogeneous topography, the river shows meandering nature from Gaumukh to Chirbas. Further downstream of Chirbas, river became braided with full of glacial debris.
Satellite imagery (LISS-III) of the area depicting the realtime scenario of land use/land cover, soil type, hydrological, geological conditions and glaciers, etc., is combined with the DEM to obtain DTM of the area. The DTM provides understanding of the geological and hydrological set-up of the area and thus greatly enhances the visual interpretation of the terrain.

\section{Aspect map (slope directional map)}

After obtaining an interpointed raster DEM, other terrain properties can be extracted using filtering techniques. First, gradients in $\mathrm{x}$ and $\mathrm{y}$ directions are derived, transforming the scalar DEM into a vector field (Fig. 6).

After creating gradients in $\mathrm{x}$ and $\mathrm{y}$ directions $\mathrm{GX}$ and GY, respectively, the absolute gradient can be used to obtain slope map as:

Slope $=(G X \times G X+G Y \times G Y)^{2}$

The map is transferred to a cell-structured simulated model and then classified as per IMSD (International Metrological Soil Department) classification (Fig. 7):

An aspect map is obtained by:

\section{Slope azimuth $=\arctan (\mathrm{GY} / \mathrm{GX})$}

In mountainous regions besides structural control, slopes are formed by mountain building processes and weathering followed by mass wasting, running water and structural control. Further, the slopes are developed by the interaction between geological and climatic factors. Therefore,

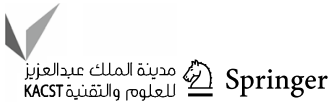


Fig. 6 Aspect map of the Gangotri glacier area

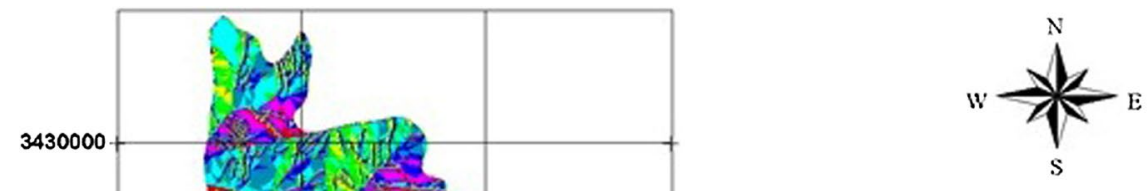

\section{Legend}

Aspect of area (Direction, Degrees)

Flat $(-1)$

North $(0-22.5,337.5-360)$

Northeast (22.5-67.5)

East (67.5-112.5)

Southeast (112.5-157.5)

South (157.5-202.5)

Southwest (202.5-247.5)

West (247.5-292.5)

Northwest (292.5-337.5)

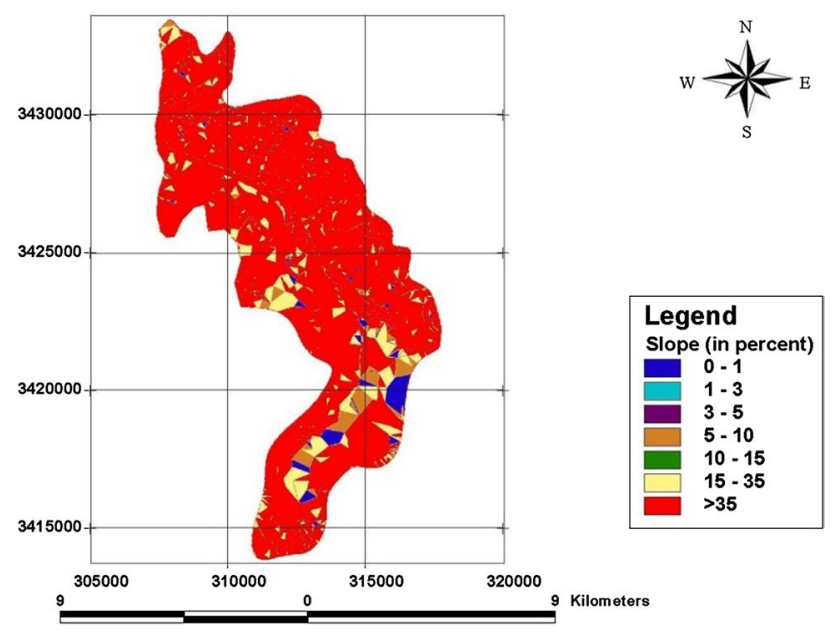

Fig. 7 Slope map (in \%) of the Gangotri glacier area

the study of slopes is useful in establishing the evolution of landforms. Slope is a significant factor, which control the run-off and the removal of sediment including weathered debris. The form and angle of slope are controlled by the nature of bedrocks and their structures and partly by the regolith. The slope directional map prepared using GIS software Arc view 8.3 is indicative of the important sites for choking of the Bhagirathi River. The map exhibits that the slope directions are parallel to the river Bhagirathi, converging from all sides to form localized basins. These localized basins are the sites where sediments accumulate to dam the river to form artificial lake. The directions parallel to river indicate the regions along which maximum transportation of sediments takes place.
Table 1 Showing areawise distribution of slope (in \%)

\begin{tabular}{llll}
\hline S. no. & Slope (in \%) & Name of slope & Area (sq. km) \\
\hline 1. & $0-1$ & Nearly level & 0.05 \\
2. & $1-3$ & Very gently sloping & 0.33 \\
3. & $3-5$ & Gently sloping & 0.51 \\
4. & $5-10$ & Moderately sloping & 1.24 \\
5. & $10-15$ & Strongly sloping & 1.70 \\
6. & $15-35$ & Steeply sloping & 7.63 \\
7. & $>35$ & Very steeply sloping & 77.00 \\
\hline
\end{tabular}

The slope map of the Gangotri glacier region shows the maximum slope of approximately $90^{\circ}$ towards the NE direction. Most of the area towards the NE direction shows the slope between $45^{\circ}$ and $90^{\circ}$ because extremely steep slopes of the area are considered as area of maximum destruction and prone to avalanche. Such area occupied around 35\% of the area of study region (Table 1).

However, the areas with minimum slopes are situated along the valley. These regions with the maximum slope of $5^{\circ}$ occupy nearly the $1 \%$ area (Fig. 8 ). The slope maps (in degrees and percentage) along with their graphical representation illustrate different degrees of slopes and their percentage $(\%)$ at different locations of the study region.

\section{Slope shape}

The entire Gangotri glacier area has been divided into three slopes as concave, convex and even (Table 2). Among the total covered area of slope study of 88.67 sq. km., 25.08 sq. 


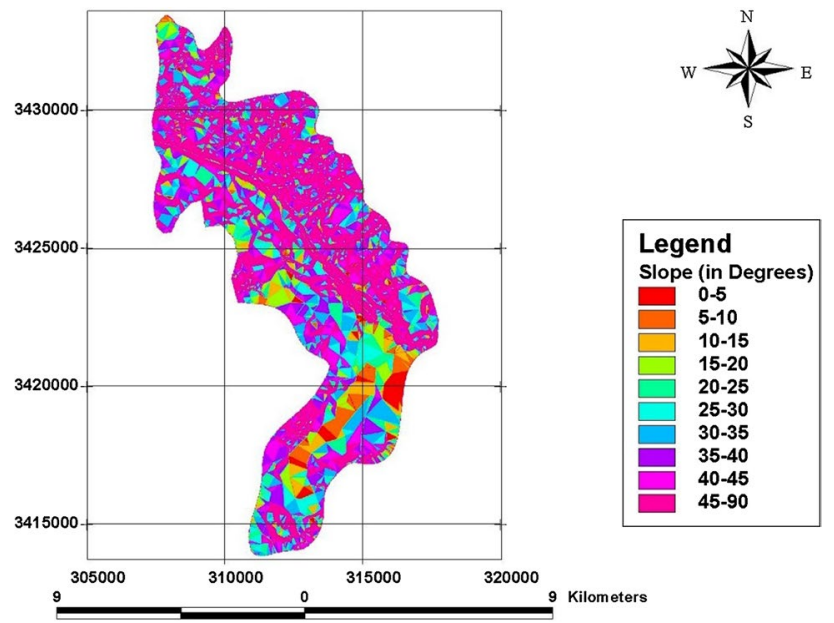

Fig. 8 Slope map (in degrees) of the Gangotri glacier area

$\mathrm{km}$ comes in convex slope, $24.55 \mathrm{sq}$. $\mathrm{km}$ area has concave slope, and even slope covers 39.03 sq. km (Fig. 9).

The geomorphological study carried out by satellite imagery LISS-III reveals that the area can easily be divided into two parts on the basis of slopes. Majority of the area in NW, SW and SE directions is composed of even slope, whereas the NE part of the study area shows concave and convex types of slope. Concave areas are easily distinguished in LISS-III image because of occurrence of water, whereas convex areas show vegetation or snow cover. These areas show extensive differential surface weathering governed by water and wind action. In addition to surface weathering, this area is tectonically active. The even slope areas (generally more than $45^{\circ}$ ) are extremely dangerous and prone to landslide and avalanches. As a testimony, a number of neotectonic activities have already been reported from this area (Bali et al, 2003). Significantly, the given area is extremely sensitive for landslides in view of variable slopes.

\section{Relief}

To workout relief of the region, it is essential to delineate different altitudinal zones (Fig. 10). These zones are marked out on topographic map on the basis of altitude, gradient and other prevailing geographical factors. The altitudinal zonation established on the basis of field and laboratory studies is confirmed by the study of Landsat imagery of the region.
The detailed altitudinal trends in the Gangotri glacier valley indicate four altitudinal zones, namely extremely high, high, medium and low (Table 3). The relief zoning has been carried out by superimposing altitudinal zones map on the nature of the terrain, the type of the slope and the altitude (Table 4).

By and large, the altitudinal zones, relief and slope are higher in the northern part and gradually decline in the southern part of the Gangotri glacier valley area.

\section{Vulnerability maps of Gangotri glacier}

Figure 11 shows vulnerability map based on slope and aspect with five major slope shapes along with their seven subslope aspects $\left(0^{\circ}-1^{\circ}, 1^{\circ}-3^{\circ}, 3^{\circ}-5^{\circ}, 5^{\circ}-10^{\circ}, 10^{\circ}-15^{\circ}\right.$, $15^{\circ}-35^{\circ}$ and $>35^{\circ}$ ). The maximum area about 20.13 sq. $\mathrm{km}$ shows slopes $>35^{\circ}$ towards east direction. The minimum slopes of same category lie in the west direction, which covers the area of $16.71 \mathrm{sq} . \mathrm{km}$.

The northern portion of the study area occupies maximum area, i.e. 25.81 sq. $\mathrm{km}$ with different slope classes (Table 5). The NE part of the area comprises of maximum slopes of all category and aspect, while the SW portion shows low undulating terrains and slopes. Thus, it is suggested that the NE portion of the area is most vulnerable for avalanche and landslide as compared to other parts.

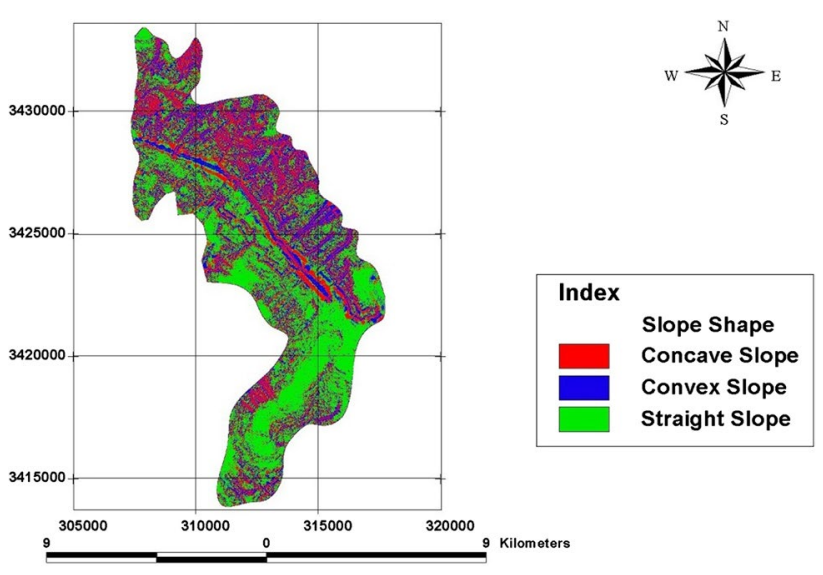

Fig. 9 Slope shape map of the Gangotri glacier area
Table 2 Slope elements: Gangotri glacier valley (Garhwal Himalaya)

\begin{tabular}{lllll}
\hline S. no. & Types of slopes & & \multicolumn{2}{l}{ Special features and locations } \\
\cline { 2 - 4 } & Top & Middle & Bottom & \\
\hline 1. & Escarpment & Concave & Convex & Break of slope at 50 m near Gaumukh \\
2. & Escarpment concave & Convex & Even & Break of slope at 100 m near Bhujgari \\
3. & Escarpment concave & Concave & Concave & Smooth steep concave slope at 50 m near Bhujbas \\
\hline
\end{tabular}


Fig. 10 Altitudinal zones of the Gangotri glacier area

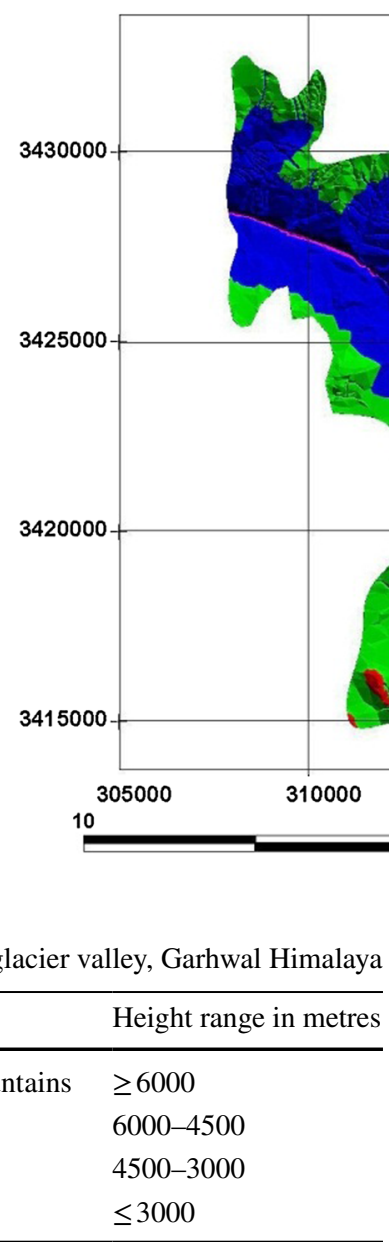

Table 3 Altitudinal zones: Gangotri glacier valley, Garhwal Himalaya

\begin{tabular}{lll}
\hline S. no. & Altitudinal zones & Height range in metres \\
\hline 1. & Zone of extremely high mountains & $\geq 6000$ \\
2. & Zone of high mountains & $6000-4500$ \\
3. & Zone of medium mountains & $4500-3000$ \\
4. & Zone of low mountains & $\leq 3000$ \\
\hline
\end{tabular}

\section{Discussion and conclusions}

The geomorphological study of the Gangotri glacier region is accomplished with remote sensing and GIS (geographical information system) techniques. The entire Gangotri glacier region is mapped through satellite data LISS-III, and different geomorphic features are represented by different models and maps, i.e. DEM, DTM, aspect map, slope degree map and altitudinal zonation map. These models and maps evidently reveal that the snout of the Gangotri glacier is situated at an altitude of about $4000 \mathrm{~m}$ and shows escalation in elevation towards SE and depletion towards NW. During winter periods, the glacier becomes more extensive while in summer the ice only persists on the peaks in a state of disequilibrium due to low ablation rates. The digital terrain model signifies that the Gangotri glacier is expanding towards high lands and its growth and shrinking are entirely controlled by climate.

The NE portion of the Gangotri glacier shows maximum drainage density while the NW portion shows the minimum drainage density. The Bhagirathi River occupies V-shaped valley through snout of Gangotri glacier, becomes U-shaped at Bhojbas and again retains V-shaped valley in downstream up to Chirbas. It is deciphered through aspect map that the NE portion of the study area covering large area of about 19.75 sq. km exhibits greater melting and melt run-off as compared to other areas, whereas the SE portion of the Gangotri glacier with less area, i.e. 8.10 sq. km, contributes minimum ablation and maximum accumulation. The present investigation analyses different degrees of slopes throughout the entire area. The entire area has been divided into three slopes, viz. concave, convex and even. Majority of the area in NW, SW and SE direction is composed of even slope, while NE portion shows concave and convex slopes. It is suggested that the NE part of the area with greater slopes $\left(45^{\circ}\right.$ to $\left.90^{\circ}\right)$ is to be considered more vulnerable for landslide
Table 4 Relief zones: Gangotri glacier valley, Garhwal Himalaya

\begin{tabular}{lll}
\hline S. no. & Relief of zones & Characteristic geomorphic features \\
\hline 1. & Zone of extremely high relief & Very high hills with convex waxing slope \\
2. & Zone of high relief & High hills with convex waxing slope \\
3. & Zone of medium relief & Hill sides with free face slope \\
4. & Zone of low relief & Foot hills with concave wanning slope \\
\hline
\end{tabular}


Fig. 11 Vulnerability map of Gangotri glacier based on slope classes with aspects
Table 5 Area and aspect of different slope classes

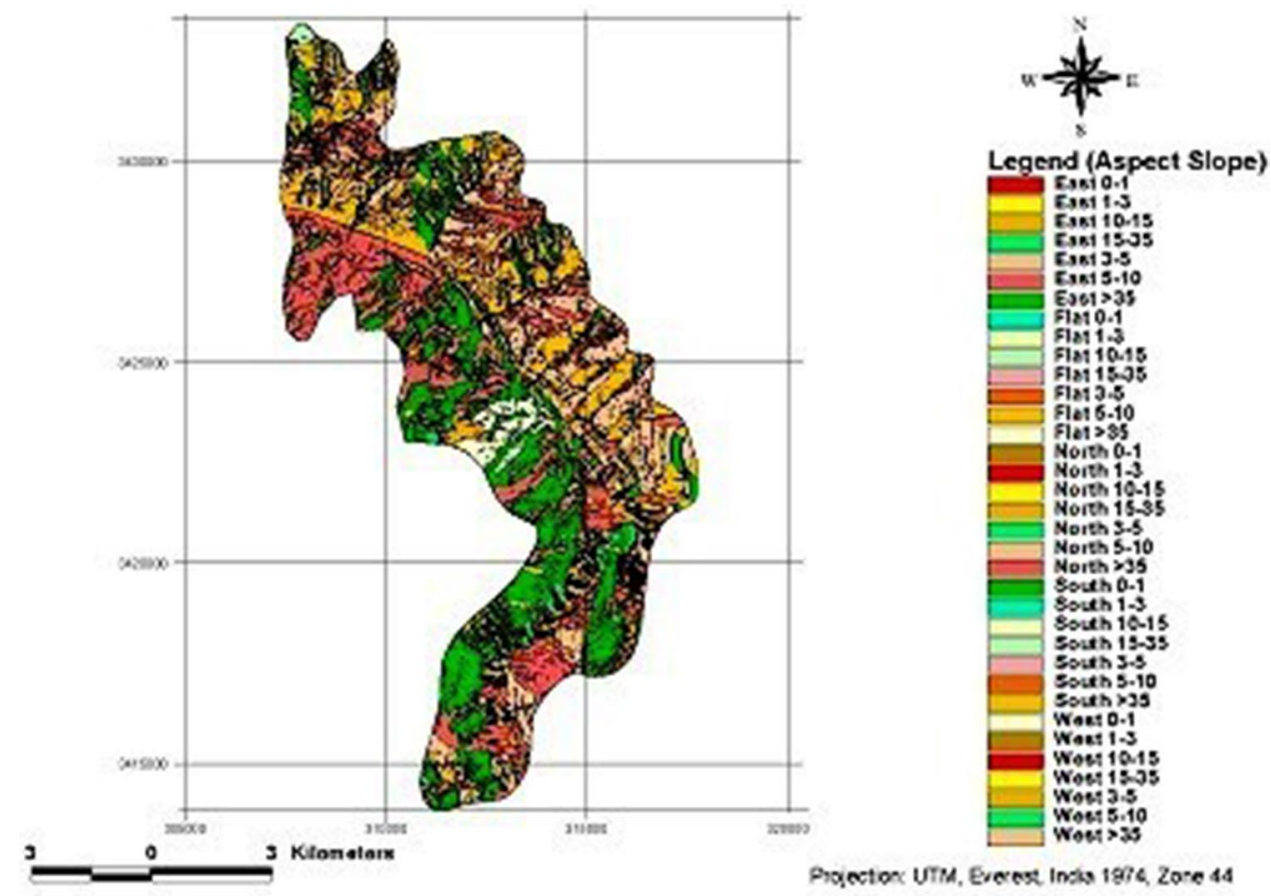

\begin{tabular}{|c|c|c|c|c|c|c|c|c|c|}
\hline S. no. & Aspect class & $0-1$ & $1-3$ & $3-5$ & $5-10$ & $10-15$ & $15-35$ & $>35$ & Grand total \\
\hline \multicolumn{10}{|c|}{$\begin{array}{l}\text { Slope classes } \\
\text { (Sum of area in square m) }\end{array}$} \\
\hline 1. & East & 0.00 & 0.03 & 0.19 & 0.56 & 0.38 & 2.52 & 20.13 & 23.83 \\
\hline 2. & Flat & 0.17 & 0.01 & 0.00 & 0.00 & 0.00 & 0.00 & 1.74 & 1.91 \\
\hline 3. & North & 0.01 & 0.08 & 0.16 & 0.77 & 0.73 & 4.18 & 19.88 & 25.81 \\
\hline 4. & South & 0.00 & 0.03 & 0.05 & 0.17 & 0.16 & 1.13 & 16.86 & 18.40 \\
\hline \multirow[t]{2}{*}{5.} & West & 0.00 & 0.04 & 0.07 & 0.29 & 0.26 & 1.35 & 16.71 & 18.72 \\
\hline & Grand total & 0.18 & 0.19 & 0.48 & 1.79 & 1.54 & 9.18 & 75.32 & 88.67 \\
\hline
\end{tabular}

and avalanche. Even slope areas (slope $>45^{\circ}$ ) are considered extremely dangerous and prone to landslide.

Acknowledgements We express our thanks to Dr. S. D. Sharma, Principal Sri Jai Narain Post Graduate College, Lucknow, for providing working facilities and continuous encouragement. We thank A. K. Tangri and Ram Chandra, RSACUP, Lucknow, for the help and cooperation during this investigation. We are thankful to Deepak Agarwal for his support in GIS analysis and word processing. We appreciate R. C. Tewari of Sri J. N. P. G. College Lucknow for reviewing the manuscript. We are grateful to D. D. Awasthi and Rameshwar Bali Department of Geology, Lucknow University, for their guidance in preparation of manuscript.

Open Access This article is distributed under the terms of the Creative Commons Attribution 4.0 International License (http://creativeco mmons.org/licenses/by/4.0/), which permits unrestricted use, distribution, and reproduction in any medium, provided you give appropriate credit to the original author(s) and the source, provide a link to the Creative Commons license, and indicate if changes were made.

\section{References}

Auden JB (1937) The snout of the Gangotri glacier, Tehri Garhwal. Rec Geol Surv India 72(2):135-140

Bali R, Awasthi DD, Tewari NK (2003) Neotectonic Control on the geomorphic evolution of Gangotri glacier valley, Garhwal Himalaya. Gondwana Res 6(4):829-838

Bali R, Awasthi DD, Tewari NK (2004) Record of neotectonic activity in Gangotri glacier valley: some significant observations. Proceeding of workshop on Gangotri glacier. Geol Survey India Spl Pub 80:79-86

Gansser A (1964) Geology of Himalays. Interscience Publishers, London, p 289

Mathew J, Jha VK, Rawat GS (2007) Weights of evidence modelling for landslide hazard zonation mapping in part of Bhagirathi valley, Uttarakhand. Curr Sci 92(5):628-638

Nainwal HC, Prased C (2002) Studies of glacial and glacio-fluvial geomorphology of Gangotri glacier in between Gaumukh and Gangotri, Garhwal Himalaya, Seminar vol. IN: (eds) Charu CP, Sharma AKAspect of geology and environment of the Himalaya. Gyanodaya, Nainital, pp 249-260 
Naithani AK, Nainwal HC, Sati KK, Prasad C (2001) Geomorphological evidences of retreat of the Gangotri glacier and its characteristics. Curr Sci 80(1):87-94

Owen LA (1989) Neotectonics and glacial deformation in the Karakoram mountains and Nanga Parbat Himalaya. Tectonophysics 163:227-265

Owen LA, Sharma MC (1998) Rates and magnitudes of paraglacial Fan formation in the Garwal Himalaya; implications for landscape evolution. Geomorphology 26:171-184

Owen LA, Benn DI, Derbishire E, Evans DJA, Mitchell WA, Thompson D, Richardson S, Lloyd M, Holden C (1995) The geomorphology \& Landscape evolution of the lahul Himalaya, Northern Indai. Geomorphol Landsc Evolut 39(2):145-174

Philip G, Ravindran KV (1998) Glacial mapping using landsat thematic mapper data: a case study in parts of Gangotri glacier, NW Himalaya. J Indian Soc Remote Sens 26(1\&2):29-34

Puri VMK, Shukla SP (1996) Tongue fluctuation studies on Gangotri Glacier, Uttarkashi Distt., Uttar Pradesh. Geol Surv Ind Spl Pub 21(2):289-291

Sangewar CV (1998) Glacier front fluctuations studies in parts of Uttar Pradesh and Himachal Pradesh. Geol Surv India Rec 130:135-136

Sharma MC, Owen LA (1996) Quaternary glacial history of NW Garhwal, Central Himalayas. Quatern Res Rev 15:335-365

Singh DS, Mishra A (2000) Gangotri glacier system, Garhwal Himalaya: an analysis using GIS technique (seminar volume). In: Pant CC, Sharma AK (eds) Aspect of geology and environment of the Himalaya. Gyanodaya Prakashan, Nainital, pp 349-358

Singh J, Yadav RR (2000) Tree-ring indication of recent glacier fluctuations in Gangotri, Western Himalaya, India. Curr Sci 79(11):1598-1601

Tangri AK (2002) Shrinking glaciers of Uttaranchal: cause of concern and hope for the future (seminar volume). In: Pant CC, Sharma
AK (eds) Aspect of geology and environment of the Himalaya. Gyanodaya Prakashan, Nainital, pp 335-348

Tewari, Sharma (2015) GIS evaluation in geomorphic studies of Gangotri glacier, Garhwal Himalaya, India. National seminar on geospatial technology and 3D applications for sustainable development of land resources. Souvenir, Remote Sensing Application and Centre, U.P., pp 15-16

Valdiya KS (1993) Uplift and geomorphic rejuvenation of the Himalaya in the quaternary period. Curr Sci 64(11\&12):873-885

Valdiya KS (2010) Reactivation of terrane-defining boundary thrusts inn central sector of the Himalaya: implications. Curr Sci 81(111):1418-1431

Yadav RR, Park WK (2000) Precipitation reconstruction using ringwidth chronology of Himalayan cedar from western Himalaya: preliminary results. Proc India Acad Sci (Earth Planet Sci) 109(3):339-345

Yadav RR, Singh J (2002) Tree ring based spring temperature pattern over the past four centuries in western Himalay. Quatern Res 57:299-305

Yadav RR, Park WK, Bhattacharya (1997) Dendroclimatic reconstruction of April-May temperature fluctuations in the western Himalaya of India since AD 1698. Quatern Res 48:187-191

Yadav RR, Park WK, Bhattacharya (1999) Spring-temperature variations in western Himalaya, India, as reconstructed from tree rings: AD 1390-1987. Holocene 9(1):85-90

Publisher's Note Springer Nature remains neutral with regard to jurisdictional claims in published maps and institutional affiliations. 